\title{
ANALISIS FAKTOR YANG MEMPENGARUHI RATING SUKUK SYARIAH DI INDONESIA
}

\author{
Farhadi Arifiansyah; Safarinda Imani; Kholid Albar \\ STEI Kanjeng Sepuh Gresik; Universitas Ibrahimy Situbondo; STEI Kanjeng Sepuh Gresik \\ e-mail: farhadi@steikassi.ac.id; safarindaimani@ibrahimy.ac.id; kholid@ steikassi.ac.id
}

\begin{abstract}
Sukuk is a form of investment and a means for companies to seek capital. Sukuk's issuance growth-increasing indicates that many investors are interested in buying Sukuk, so that many companies are also interested in issuing Sukuk. The more Sukuk issuances, the more important the rating of the Sukuk for investors and companies will issue Sukuk. The research aims to analyze the factors that affect the rating of Sukuk, such as corporate governance, financial ratios, market value, secure and types of Sukuk. The next goal is that the results of this study are expected to be a consideration for investors in determining investment in Sukuk and for companies to be considered in issuing Sukuk. This study uses secondary data obtained from the annual reports of corporate companies listed on the Indonesia Stock Exchange and rated by PT PEFINDO. The analysis technique in this study uses multinomial logistic regression with the SPSS 25. tool. The result of this study indicates that the CEO-Chairman Duality variable has a significant value of 0.037, the number of commissioners has a significant value of 0.001, commissioner independence is significant 0.035. Profitability has a significant value of 0.008, and leverage has a significant value of 0.044, liquidity has a significant value of 0.000. Market value using the stock price variable has a significant value of 0.006. The Secure variable has a significant value of 0.012. The type of Sukuk has a significant value of 0.000, so all variables in this study are considered to affect the Sukuk rating.
\end{abstract}

Keywords: Sukuk rating; corporate governance; financial ratios; type of Sukuk; Islamic finance

\section{Pendahuluan}

Akitivitas ekonomi pada suatu negara tidak akan terlepas dari norma sosial, adat, politik, lingkungan serta orang-orang yang akan meneruskan perjuangan bangsa. Asas ekonomi pada suatu negara adalah memenuhi semua kebutuhan setiap individu anggota masyarakat, begitu pula tata kelola perekonomiannnya pasti dikelola secara baik dengan tujuan untuk meratanya pembagian pendapatan, kekayaan serta kesempatan kerja yang sama sesuai dengan kontribusi setiap individu.

Perputaran perekonomian suatu negara juga tidak terlepas dari kelompok-kelompok yang memerlukan modal maupun kelompok yang mempunyai modal berlebih, dalam hal ini adalah perusahaan dan investor. Modal menjadi salah satu kebutuhan sebuah bagi perusahaan. Banyak cara yang dilakukan oleh pemilik perusahaan untuk mendapatkan modal, seperti berhutang pada bank dan menerbitkan surat-surat berharga perusahaan. Dalam hal ini, suratsurat berharga seperti saham, obligasi maupun sukuk atau surat berharga lainnya diterbitkan pada pasar modal. Pada kondisi ini, peranan dari pasar modal sendiri sangat penting bagi para perusahaan yang membutuhkan dana. Lembaga ini menjadi pihak perantara bertemunya 
perusahaan dengan pemilik modal lebih atau investor. Bagi perusahaan yang ingin menjual saham atau surat berharga di pasar modal harus melakukan initial public offering (IPO) atau penawaran saham perdana kepada publik. Dalam teori stakeholder dinyatakan bahwa keberadaan perusahaan bergantung pada dukungan dari stakeholder atau pemilik surat berharga, kreditur, konsumen, pemerintah, masyarakat dan pihak lain yang terlibat. ${ }^{1}$

Dalam pasar modal sendiri terdapat pasar modal syariah, yaitu perdagangan di dalam lingkup pasar modal yang diatur dalam undang-undang pasar modal dengan tetap mengikuti prinsip-prinsip syariah. Di Indonesia sendiri pasar modal syariah mengawali peresmiannya pada tanggal 3 Juli 1997 dengan penerbitan perdana reksadana syariah yang dipelopori oleh PT. Danareksa Investment Management. Setelah itu, Bursa Efek Indonesia bekerjasama dengan PT. Danareksa Investment Management meresmikan Jakarta Islamic Index pada tanggal 3 Juli 2000 dengan maksud sebagai panduan bagi para investor yang ingin menanamkan modalnya di pasar modal syariah. Instrumen penyertaan modal yang diperjualbelikan dalam pasar modal syariah adalah kumpulan dari saham-saham syariah atau biasa disebut dengan Jakarta Islamic Index (JII) di mana saham yang masuk pada JII adalah kurasi dari saham-saham yang tata kelolanya perusahannya tidak berberlawanan dengan prinsip-prinsip syariah, begitu juga reksadana syariah, dan obligasi syariah dengan sistem filter tata kelola perusahaan yang sama dengan JII.

Dewan Syariah Nasional Majelis Ulama Indonesia (DSN-MUI) pada tahun 2002 mengeluarkan Fatwa Nomor 32/DSN-MUI/IX/2002 mengenai obligasi syariah dan saat ini lebih dikenal dengan istilah sukuk. Sukuk adalah surat berharga jangka panjang di mana kegiatan dari tata kelola perusahaan penerbitnya dan dasar perjanjiannya mengacu pada prinsip-prinsip syariah yang kemudian diterbitkan oleh emiten kepada pihak yang memiliki hak atas sukuk. Kewajiban emiten ketika menerbitkan sukuk adalah membayar margin atau bagi hasil pendapatan sesuai dari porsi kepemilikan sukuk dan mengembalikan dana sukuk ketika perjanjian tersebut berakhir atau pada saat tempo waktu pembayaran.

Sukuk menjadi salah satu pilihan perusahaan dalam mencari pendanaan, mengingat Indonesia sebagai negara yang memiliki jumlah penduduk muslim terbesar di dunia. Sehingga, diharapkan dari penerbitan sukuk tersebut para investor muslim baik di Indonesia maupun dari luar negeri lebih tertarik untuk berinvestasi di Indonesia. Strategi yang dapat diterapkan untuk dikembangkan pada pasar sukuk di negara ini adalah dengan mengembangkan standar moral investor, mengoptimalkan peran pemerintah dalam mengidentifikasi aset, dan mengkoordinasi ketentuan pelatihan untuk legislator tentang pendekatan terhadap sukuk.

Di Indonesia sendiri penerbit sukuk terdiri dari dua segmen, yaitu sukuk yang dikeluarkan oleh pemerintah dan sukuk yang diterbitkan oleh perusahaan korporasi. Dari tahun 2014-2019 nilai sukuk korporasi terus naik secara signifikan, artinya banyak perusahaan yang tertarik untuk menerbitkan sukuk dan banyak juga investor yang tertarik untuk membeli sukuk. Dari banyaknya emiten ataupun investor yang tertarik pada sukuk, maka penilaian sukuk atau pemeringkatan pada sukuk juga sangat penting, manfaat bagi perusahaan salah satunya sebagai pertimbangan pada saat akan menerbitkan sukuk dan bagi investor untuk menentukan ke mana dana mereka akan diinvestasikan.

\footnotetext{
${ }^{1}$ Imam Ghozali dan Anis Chariri, Teori Akuntansi (Semarang: Badan Penerbit UNDIP, 2007), 62.
} 
Semakin banyak penerbitan sukuk, maka rating sukuk menjadi penting bagi investor sebagai pertimbangan ke mana dananya akan diinvestasikan. Di sinilah teori "signal" berlaku di mana tindakan yang diambil oleh perusahaan penerbit sukuk berusaha memberi petunjuk atau informasi kepada investor tentang langkah-langkah manajemen dalam menentukan peluang perusahaan ke depan. Teori ini menjelaskan mengenai keputusan yang sudah dilakukan manejemen perusahaan dalam merealisasikan keinginan para pemegang saham. Informasi ini menjadi bahan pertimbangan untuk para pemilik dana dan pelaku bisnis karena memberi informasi berupa keterangan, catatan dan gambaran track record perusahaan pada kondisi terdahulu, sekarang ataupun prospek ke depan dalam kesinambungan perusahaan tersebut. Namun informasi yang didapatkan oleh investor tidak selalu sesuai dengan yang terjadi di dalam perusahaan, seperti kondisi ketidakseimbangan informasi yang diperoleh pihak-pihak yang memiliki kepentingan dalam perusahaan. Kondisi ini disebabkan oleh adanya salah satu pihak yang dinilai mendapatkan akses informasi yang lebih dominan dari pada pihak lainnya. Pada kondisi ini bagian manajemen sebagai lingkup dari intern perusahaan dinilai memiliki akses informasi yang lebih baik daripada pihak lain di luar perusahaan. ${ }^{2}$ Penentuan rating menjadi penting bagi investor maupun perusahaan penerbit sukuk karena akan menjadi pertimbangan dalam memilih atau menerbitkan sukuk. Salah satu lembaga yang bertindak sebagai pemeringkat efek dan diakui kredibiltas dan independensinya oleh OJK adalah PT. PEFINDO.

Dalam penelitian kustyaningrum ${ }^{3}$ dengan sampel 33 perusahaan yang dirating oleh PT. PEFINDO menggunakan analisis regresi logistik dengan variabel bebas leverage, profitabilitas, umur obligasi likuiditas serta rating obligasi sebagai variabel dependen menghasilkan secara parsial peringkat obligasi tidak dipengaruhi oleh variabel leverage, umur sukuk dan profitabilitas, sebaliknya peringkat obligasi dipengaruhi oleh variabel likuiditas. Namun secara keseluruahn pada uji simultan peringkat obligasi bersama-sama dipengaruhi variabel bebas leverage, likuiditas, profitabilitas, dan umur obligasi.

Menurut pramesti ${ }^{4}$ dalam penelitiannya tentang pemeringkatan sukuk dalam perspektif keuangan pada perusahaan penerbit sukuk di BEI tahun 2010-2015 dengan memakai variabel independen berupa profitabilitas, likuiditas dan firm size menghasilkan ROA sebagai proksi dari variabel profitabilitas berkontribusi positif pada rating sukuk yang diteliti. Hal ini menginterpretasikan apabila nilai profit dari perusahaan semakin tinggi, maka rating sukuk yang didapat juga semakin tinggi. Hal sama disebutkan bahwa rating sukuk dipengaruhi oleh variabel firm size yang diukur dengan menggunakan total asset menyatakan variabel size. Sebaliknya peringkat sukuk dipengaruhi secara negatif oleh likuiditas dengan current ratio sebagai proksi pada penelitian tersebut.

Sedangkan amirah ${ }^{5}$ dalam penelitian dengan objek 43 penerbitan sukuk di Malaysia dari tahun 2006-2015 menggunakan variabel firm size, profitabilitas, secure dan jenis sukuk dalam

\footnotetext{
${ }^{2}$ Michael Spence, "The Quarterly Journal of Economics”, Job Market Signaling, Volume 87, Nomor 3 (1973), 357.

${ }^{3}$ Dinik Kustiyaningrum, dkk, "Pengaruh Leverage, Likuiditas, Profitabilitas, dan Umur Obligasi Terhadap Peringkat Obligasi (Studi Pada Perusahaan Terbuka yang Terdaftar di Bursa Efek Indonesia)", Assets: Jurnal Akuntansi dan Pendidikan, Volume 5, Nomor 1 (2017), 25.

4 Wahyu Pramesti, "Analisis Pemeringkatan Sukuk: Perspektif Keuangan", BISNIS: Jurnal Bisnis dan Manajemen Islam, Volume 5, Nomor 1 (2018), 93.

${ }^{5}$ Dinik Kustiyaningrum, dkk, "Pengaruh Leverage, Likuiditas", 26.
} 
menentukan peringkat sukuk menggunakan analisis multinominal logistic regression hasilnya tiga dari empat variabel mempengaruh peringkat sukuk, yaitu profitabilitas, status jaminan sukuk dan jenis sukuk. Dalam penelitian raimuna ${ }^{6}$ mengenai faktor dari sisi akuntansi dan non akuntansi yang dapat mempengaruhi rating sukuk dengan penelitan pada emiten sukuk yang terdaftar di JII selama periode 2012-2015 dengan metode analisis regresi berganda dan menggunakan variabel independen akuntansi (leverage dan likuiditas) dan non akuntansi (umur Sukuk, jaminan sukuk) menghasilkan leverage dan likuiditas tidak memiliki kontribusi pada rating sukuk, sebaliknya umur dan jaminan pada sukuk berkontribusi terhadap rating sukuk. Namun pada uji simultan peringkat sukuk secara bersama-sama dipengaruhi oleh leverage, likuiditas, umur serta jaminan pada emiten penerbit sukuk yang terdaftar di JII 2012-2015.

Melihat hasil dari penelitian sebelumnya memiliki beberapa perbedaan hasil penelitian dan juga sebagai alat untuk mempermudah investor dalam negeri dalam menganalisa sukuk secara mandiri serta menjadi pertimbangan untuk perusahaan dalam menerbitkan sukuk, sehingga pada penelitian mengenai rating sukuk korporasi dengan objek perusahaan penerbit sukuk di Indonesia yang dirating oleh PT. PEFINDO dengan menggunakan variabel corporate governance, rasio keuangan, nilai pasar, secure dan jenis sukuk sebagai variabel independen yang diharapkan dapat mewakili setiap aspek yang dapat mempengaruhi rating sukuk pada perusahaaan korporasi di Indonesia.

\section{Metodologi Penelitian}

Metode dalam penelitian ini adalah metode kuantitatif karena data dalam penelitian berupa angka-angka dan dianalisis menggunakan statistik. ${ }^{7}$ Metode analisis yang digunakan dalam penelitian ini adalah Metode Analisis Regresi Multinominal Logistik. Populasi adalah lingkup secara umum terdiri dari objek/subjek yang mempunyai kualitas dan karakteristik tertentu serta bisa diterapkan oleh peneliti guna dipelajari dan kemudian ditarik kesimpulannya. ${ }^{8}$ Sedangkan sampel merupakan bagian dari total karakteristik yang ada pada populasi. Data untuk penelitian ini menggunakan data sekunder yang telah dikumpulkan oleh lembaga dan dipublikasikan pada pengguna data. Teknik pengumpulan data dengan cara dokumentasi yakni melihat laporan keuangan, seperti annual report perusahaan korporasi di Indonesia dan tercatat di Bursa Efek Indonesia dan dirating oleh PT. PEFINDO yang diperoleh dari website resmi masing-masing perusahaan dari tahun 2014-2019.

Teknik analisisis data ini menggunakan Regresi Multinominal Logistik di mana model ini merupakan binary logistic, yaitu variabel dependennya berbentuk lebih dari dua kategori. Analisis regresi logistik tidak membutuhkan uji normalitas dan uji asumsi klasik pada variabel independennya. Teknik pengujian dilakukan dengan tahapan analisis deskriptif dan selanjutnya uji signifikansi meliputi uji model fitting information, uji goodness of fit, uji Pseudo R-Square, dan uji likelihood ratio test guna mengevaluasi model sehingga diketahui

\footnotetext{
${ }^{6}$ Ibid.

${ }^{7}$ Sugiyono, Metode Penelitian Kuantitatif Kualitatif dan R\&D (Bandung: Alfabeta, 2012), 51.

${ }^{8}$ Ibid.
} 
hubungan antar variable. ${ }^{9}$ Berikut model persamaan regresi multinomial logistik pada penelitian ini:

Logit $\frac{\mathrm{p} 1}{\mathrm{p} 2}=\alpha_{0}+\beta_{1} \mathrm{DCC}+\beta_{2} \mathrm{JK}+\beta_{3} \mathrm{KI}+\beta_{4} \mathrm{PROFIT}+\beta_{5} \mathrm{LVRG}+\beta_{5} \mathrm{LIKUID}+\beta_{6} \mathrm{HS}+\beta_{7} \mathrm{SC}+$ $\beta_{8} \mathrm{JS} *(\mathrm{Dp})$

Keterangan:

$\alpha_{0} \quad$ : Nilai constant.

B1-8 : Masing-masing koefisien pada prediktor $\mathrm{X}$.

DCC : Dualitas CEO-Chairman

JK : Jumlah Komisaris

KI : Komisaris Independen

PROFIT : Profitabilitas

LVRG : Leverage

LIKUID : Likuiditas

HS : Harga Saham

SC : Secure

JS : Jenis Sukuk

Dp : variabel dummy/binary

Sedangkan tahapan pada uji multinominal logistic meliputi pertama, model fitting information yang bertujuan untuk melihat pengaruh variabel bebas terhadap variabel terikat. Pada pengujian ini analisis yang dilakukan adalah membandingkan nilai antara nilai -2 Log Likehood awal (intercept only) dengan nilai -2 Log Likehood pada model final. Pengujian model dengan variabel independen memberikan akurasi yang lebih baik jika -2 Log Likehood awal (intercept only) terjadi penurunan nilai pada -2 Log Likehood model final. Kedua, uji goodness of fit test (uji G) yang digunakan untuk menguji kelayakan model agar penjelasan pengaruh seluruh variabel independen $\left(\mathrm{X}_{1}, \mathrm{X}_{2}, \mathrm{X}_{3}, . ., \mathrm{X}_{\mathrm{n}}\right)$ terhadap variabel dependen (Y) layak dilakukan. Nilai Uji Goodness of Fit Test selanjutnya dibandingkan dengan nilai tabel chi square dengan kriteria pengambilan keputusan adalah model yang dibuat cocok dengan data yang ada $\left(\mathrm{H}_{0}\right)$, dan model yang dibuat tidak cocok dengan data yang ada $\left(\mathrm{H}_{1}\right)$ di mana $\mathrm{H}_{0}$ ditolak jika $\mathrm{P}>0,05$ dan sebaliknya $\mathrm{H}_{0}$ diterima jika $\mathrm{P}<0,05$.

Ketiga, analisis Pseudo R-Square yang bertujuan untuk mengetahui tingkat ketepatan paling baik dalam menganalisis regresi di mana hal tersebut ditunjukkan oleh besarnya Pseudo R-Square. Pada regresi multinomial logistik nilai Pseudo R-Square terdapat 3 nilai, yaitu Cox and Snell, Negelkerke dan McFadden. Dan keempat, analisis likelihood ratio test yang bertujuan untuk mengetahui kontribusi setiap variabel independen terhadap model. Selain itu juga digunakan untuk menguji nilai signifikansi dari setiap variabel independen. Variabel yang menunjukkan kontrubusi pada model dan pengaruh signifikan dilihat pada model akhir -2 log-likelihood, jika nilai signifikansi $(\mathrm{p}<0,05)$ maka variabel independen memiliki kontribusi.

\footnotetext{
${ }^{9}$ Imam Ghozali, Aplikasi Analisis Multivariate dengan Program IBM SPSS 21 (Semarang: Badan Penerbit Universitas Diponegoro, 2013), 72.
} 


\section{Sukuk Syariah}

Keputusan Ketua Badan Pengawas Pasar Modal dan Lembaga Keuangan Nomor KEP130/BL/2006 tanggal 23 November 2006 mengenai penerbitan efek syariah menyatakan bahwa dalam hal ini sukuk sebagai bentuk dari efek syariah yang berupa surat berharga atau bukti atas hak milik aset yang bernilai sama dan mempunyai bagian dari pengikut sertaan yang tidak terpisahkan atau terbagi menjadi hak milik aset berwujud tertentu, nilai hak milik manfaat serta jasa atas proyek tertentu atau aktivitas investasi tertentu. Sedangkan sukuk sendiri adalah surat berharga yang memiliki nilai sama sebagai bagian pengganti atas hak kepemilikan sepenuhnya terhadap aset, hak guna manfaat serta jasa maupun aset dari suatu proyek atau aktifitas investasi. ${ }^{10}$

Bersumber pada keputusan DSN-MUI yang menyatakan beberapa dasar mengenai obligasi syariah yang termuat dalam Fatwa DSN-MUI Nomor 32/DSN-MUI/IX/2002 bahwa obligasi syariah berlandaskan pada al-Quran:

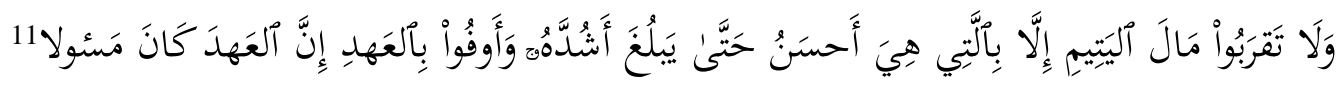

"Dan janganlah kamu mendekati harta anak yatim kecuali dengan cara yang lebih baik (bermanfaat) sampai ia dewasa dan penuhilah janji. Sesungguhnya janji itu pasti dimintai pertanggunganjawabannya”.

\section{Jaminan dan Jenis Sukuk}

Dalam bahasa Arab, jaminan dikenal dengan istilah al-rahn. Menurut al-Zuhaily, secara harfiah al-rahn berarti al-thubut dan al-dawam, yaitu tetap dan lestari, juga bisa diartikan sebagai al-habsu dan al-luzum yang artinya penahanan dan pasti ${ }^{12}$ di mana penahanan dimaksudkan sebagai penahanan terhadap suatu barang dengan hak sehingga dapat dijadikan sebagai pembayaran dari barang tersebut. ${ }^{13}$

Menurut Brister, investor atau penanam modal akan lebih berminat pada obligasi yang memiliki underlying asset atau jaminan dari pada obligasi yang tidak memiliki jaminan. Oleh sebab itu, jika obligasi atau sukuk dijamin menggunakan aset yang bernilai tinggi, maka peringkat dari obligasi atau sukuk tersebut menjadi lebih tinggi dan dengan menjaminkan aset tersebut diharapkan perusahaan bisa menekan risiko yang akan dihadapi. Berdasarkan jenis jaminan obligasi atau sukuk dapat dibagi menjadi dua jenis, yaitu obligasi atau sukuk yang dijamin dan obligasi atau sukuk yang tidak dijamin. ${ }^{14}$

Jenis sukuk adalah macam-macam bentuk akad yang diterapkan dalam sukuk. Menurut standar syariah yang ditetapkan oleh The Accounting and Auditing Organization for Islamic Financial Institutions (AAOIFI), ada beberapa macam akad yang bisa diterapkan dalam

\footnotetext{
${ }^{10}$ Nurul Huda dan Edwin Mustafa Nasution, Investasi Pada Pasar Modal Syariah (Jakarta: Kencana, 2007), 114.

11 Al-Quran, 17: 34.

${ }^{12}$ Wahbah al-Zuhaily, al-Fiqh al-Islam wa Adillatuhu (Fiqh Muamalah Perbankan Syariah), Tim Counterpart Bank Muamalat Indonesia (Jakarta: Bank Muamalat Indonesia, 1999), 163.

${ }^{13}$ Rahmat Syafei, Fiqh Muamalah (Bandung: Pustaka Setia, 2000), 67.

${ }^{14}$ Bill M. Brister, dkk, "The Regulation Effect of Credit Ratings on Bond Interest Yield: The Case of Junk Bonds", Journal of Business Finance \& Accounting, Volume 21, Nomor 4 (1994), 515.
} 
penerbitan sukuk, ${ }^{15}$ yaitu akad ijärah, murabahah, salam, istiṣnā', mushārakah, mudärabah, wakalah, muzära'ah, dan musāqah.

\section{Rating Sukuk}

Peringkat sukuk sendiri bermakna bentuk penilaian yang diberikan oleh lembaga pemeringkat sukuk terkemuka, sehingga dapat menginterpretasi sejauh mana kemampuan dan kesediaan emiten sukuk untuk memenuhi pembayaran sesuai dengan perjanjian. Proses dari penerbitan sukuk sendiri adalah guna mempengaruhi pasar internasional agar mau menanamkan modal dan menambah minat para investor serta sebagai acuan untuk menetapan harga. Jika rating sukuk semakin baik maka potensi investor yang tertarik juga akan semakin banyak. $^{16}$

Berdasarkan Surat Edaran yang diterbitkan oleh Otoritas Jasa Keuangan (OJK) 37/SEOJK/2016 yang menyatakan bahwa lembaga pemeringkat adalah salah satu bagian yang memiliki fungsi penting dalam menunjang operasional struktur keuangan, seperti dalam membantu terwujudnya transparansi pada pasar keuangan serta memembantu mempercepat penanaman modal yang efektif dan membantu dalam mendukung rencana percepatan pertumbuhan ekonomi. Dalam surat edaran yang sama, lembaga perating bisa diakui oleh Otoritas Jasa Keuangan (OJK) apabila lembaga perating bisa memenuhi standar penilaian, yaitu pertama, independensi yang berfungsi menentukan sejauh apa lembaga pemeringkat bebas dari berbagai macam kepentingan baik berhubungan langsung atau tidak dengan pemeringkatan, seperti dalam hal ekonomi, sosial dan atau politik. Kedua, obyektivitas yang berfungsi menunjukan tingkat kemampuan lembaga pemeringkat dari segi obyektivitas dalam proses pemeringkatan dan keefektifan, seperti prosedur, metodologi, kewajaran dan konsistensi. Ketiga, pengungkapan publik. Tolak ukur ini berfungsi menilai dari sisi pengungkapan lembaga pemeringkat yang diberikan kepada publik sehingga publik maupun otoritas berwajib bisa menilai tingkat independensi, obyektivitas, kapabilitas, dan operasional yang sesuai dengan ketentuan yang berlaku. Keempat, sumber daya sebagai tolak ukur berfungsi menilai kapabilitas dalam memberi jasa pemeringkatan agar dapat beroperasi secara independen dan profesional dilihat dari segi sumber daya manusia (SDM), financial support ataupun shareholder support. Kelima, transparansi pemeringkatan yang menentukan tingkat transparansi dari lembaga pemeringkat pada masyarakat luas atas semua informasi yang berhubungan dengan hasil pemeringkatan termasuk asumsi serta dasar dari penenentuan hasil pemeringkatan. Keenam, kredibilitas yang berfungsi menilai reliabilitas dan penerimaan pasar terhadap lembaga pemeringkat selaku fasilitator dalam penentuan pemeringkatan yang teruji.

Penentuan rating diperlukan guna mencerminkan kemampuan para penerbit surat berharga dalam memenuhi kewajibannya sesuai dengan perjanjian. Pada saat posisi nilai rating sukuk tinggi diharapkan bisa menambah keinginan para penanam modal untuk melakukan investasi pada sukuk yang diterbitkan.

\footnotetext{
${ }^{15}$ Rudi Bambang Trisilo, "Penerapan Akad Pada Obligasi Syariah dan Sukuk Negara (Surat Berharga Syariah Negara/SBSN)", Economic: Journal of Economic and Islamic Law, Volume 4, Nomor 1 (2014), 94. ${ }^{16}$ Ibid.
} 


\section{Corporate Governance dalam Islam}

Corporate governance dalam Islam adalah sistem yang mengarahkan dan mengendalikan perusahaan untuk memenuhi tujuan perusahaan dengan melindungi kepentingan dan hak semua stakeholder dengan menggunakan konsep dasar pengambilan keputusan berdasarkan epistemologi sosial-ilmiah Islam yang didasarkan pada ketauhidan Allah. ${ }^{17}$ Islamic corporate governance mempertimbangkan efek hukum syariah dan prinsip ekonomi dan keuangan Islam pada praktek dan kebijakan, misalnya pada lembaga zakat, pelarangan spekulasi, dan pengembangan sistem ekonomi yang didasarkan pada bagi hasil. ${ }^{18}$

Tujuan dari corporate governance secara umum adalah memberikan value lebih bagi pihak-pihak yang memiliki kepentingan. Ada lima poin utama dari good corporate governance, ${ }^{19}$ yaitu menjaga hak serta kepentingan shareholder, menjaga hak dan kepentingan anggota stakeholders non pemegang saham, menambah value perusahaan dan shareholder, menaikkan mutu efisiensi serta efektifitas kerja dewan komisaris dan manajemen perusahaan, dan menambah kualitas hubungan antara dewan komisaris dengan manajemen senior perusahaan.

Selain pentingnya tujuan dari corporate governance, manfaat dari penerapannya juga sangat penting bagi keberlangsungan perusahaan serta kestabilan kondisi perekonomian. Adapun manfaat dari corporate governance ${ }^{20}$ adalah pertama, meningkatnya kinerja perusahaan dari segi supervisi maupun pengawasan kinerja manajemen perusahaan, sehingga pertanggungjawaban manajemen terhadap stakeholder dapat terpenuhi dan tetap berasas pada peraturan yang berlaku. Kedua, dapat dijadikan sebagai matriks acuan untuk melakukan pengawasan melalui mekanisme checks and balanced sehingga efektifitas di dalam perusahaan dapat dijalankan. Ketiga, mengurangi tambahan cost yang harus dibebankan kepada pemegang saham karena risiko dari pengalihan tanggung jawab kepada pihak manajemen. Keempat, menekan pengeluaran modal yang dikeluarkan karena baiknya tata kelola perusahaan akan menurunkan persentase dari dampak risiko yang dihadapi perusahaan. Kelima, menambah nilai pasar perusahaan dan bisa mendorong impresi yang positif di mata masyarakat.

\section{Deskripsi Hasil Penelitian}

Data yang digunakanan merupakan data tahunan dari perusahaan penerbit sukuk tahun 2014 hingga 2018 dengan syarat terdaftar di Bursa Efek Indonesia dan dirating oleh PT PEFINDO. Diolah dengan tehnik analisisis regresi multinominal logistik menggunakan softwere SPSS 25.

\footnotetext{
${ }^{17}$ Najmuddin, Manajemen Keuangan dan Aktualisasi Syar'iyyah Modern (Yogyakarta: Andi, 2011), 93.

${ }^{18}$ Ishaq Bhatti dan Maria Bhatti, "Development in Legal Issues of Corporate Governance in Islamic Finance", Journal of Economic and Administrative Sciences, Volume 25, Nomor 1 (2009), 77.

${ }^{19}$ Siswanto Sutojo dan E. John Aldridge, Good Corporate Governance: Tata Kelola Perusahaan yang Sehat (Jakarta: PT. Damar Mulia Pustaka, 2005), 135.

${ }^{20}$ Mas Achmad Daniri, Konsep dan Penerapan Good Corporate Governance dalam Konteks Indonesia (Jakarta: Ray Indonesia, 2006), 126.
} 
Tabel 1.1. Descriptive Statistics

\begin{tabular}{|l|c|r|r|r|r|}
\hline & $\mathrm{N}$ & Minimum & Maximum & Mean & $\begin{array}{c}\text { Std. } \\
\text { Deviation }\end{array}$ \\
\hline DCC & 31 & 0 & 1 &, 10 &, 201 \\
JK & 31 & 4 & 10 & 5,94 & 1,948 \\
IK & 31 & 20 & 60 & 36,70 & 7,617 \\
\hline PROF & 31 &,- 01 & 0,11 &, 0464 &, 03015 \\
LVRGR & 31 &, 01 & 6,40 & 1,5184 & 1,61625 \\
LKUID & 31 &, 40 & 2,66 & 1,4865 &, 65897 \\
HS & 31 &, 35 & 7,45 & 2,2245 & 1,91092 \\
SCR & 31 & 0 & 1 &, 52 &, 508 \\
JS & 31 & 0 & 1 &, 52 &, 508 \\
RATING & 31 & 7 & 9 & 7,81 &, 910 \\
Valid N (listwise) & 31 & & & & \\
\hline
\end{tabular}

Tabel 1.1. di atas menunjukkan hasil pengamatan nilai $\mathrm{N}$ dalam penelitian sebanyak 31 jumlah sampel dengan hasil statistik deskriptif dijelaskan sebagai berikut, yaitu variabel rating memiliki nilai minimum sebesar 7 dengan nilai maksimum sebesar 9 dengan nilai rata-rata 7,81 dan simpangan baku sebesar 0,910. Variabel dualitas CEO-Chairman (DCC) memiliki nilai minimum sebesar 0 nilai maksimum sebesar 1 dengan nilai rata-rata 0,10 dan simpangan baku sebesar 0,201. Variabel jumlah komisaris (JK) memiliki nilai minimum sebesar 4 nilai maksimum sebesar 10 dengan nilai rata-rata 5,94 dan simpangan baku sebesar 1,948. Variabel independensi komisaris (IK) memiliki nilai minimum sebesar 20 nilai maksimum sebesar 60 dengan nilai rata-rata 36,70 dan simpangan baku sebesar 7,617. Variabel profitabilitas (PROF) memiliki nilai minimum sebesar $-0,1$ dan nilai maksimum sebesar 0,11 nilai rata-rata 0,0464 dengan simpangan baku sebesar 0,03015. Variabel leverage (LVRGR) memiliki nilai minimum sebesar 0,1 nilai maksimum sebesar 6,40 nilai rata-rata 1,5184 dan simpangan baku sebesar 1,61625. Variabel likuiditas (LKUID) memiliki nilai minimum sebesar 0,40 nilai maksimum sebesar 2,66 nilai rata-rata 1,4865 dan simpangan baku sebesar 0,65897. Variabel harga saham (HS) memiliki nilai minimum sebesar 0,35 nilai maksimum sebesar 7,45 nilai rata-rata 2,2245 dan simpangan baku sebesar 1,91092. Variabel secure (SCR) memiliki nilai minimum sebesar 0 dan nilai maksimum sebesar 1 dengan nilai rata-rata 0,52 dan simpangan baku sebesar 0,508. Variabel jenis sukuk (JS) memiliki nilai minimum sebesar 0 nilai maksimum sebesar 1 dengan nilai rata-rata 0,52 dan simpangan baku sebesar 0,508.

\section{Uji Model Fitting Information}

Pengujian model fitting information bertujuan untuk melihat pengaruh dari variabel independen, yaitu dualitas CEO-Chairman, jumlah komisaris, independensi komisaris, profitabilitas, leverage, likuiditas, harga saham, secure dan jenis sukuk terhadap rating sukuk. Pada pengujian ini, analisis yang dilakukan adalah membandingkan nilai antara -2 Log Likehood awal (intercept only) dengan nilai -2 Log Likehood pada model final. Model dengan 
variabel independen memberikan akurasi yang lebih baik jika terjadi penurunan antara nilai -2 Log Likehood awal (intercept only) dengan nilai -2 Log Likehood pada model final. ${ }^{21}$

Tabel 1.2. Model Fitting Information

\begin{tabular}{|c|r|r|r|r|}
\hline \multirow{2}{*}{ Model } & $\begin{array}{c}\text { Model Fitting } \\
\text { Criteria }\end{array}$ & \multicolumn{3}{|c|}{ Likelihood Ratio Tests } \\
\cline { 2 - 5 } & $\begin{array}{c}\text {-2 Log } \\
\text { Likelihood }\end{array}$ & Chi-Square & df & Sig. \\
\hline $\begin{array}{c}\text { Intercept } \\
\text { Only }\end{array}$ & 62,038 & & & \\
\hline Final & 16,799 & 45,239 & 18 &, 000 \\
\hline
\end{tabular}

Dari tabel 1.2. di atas dapat dilihat bahwa nilai -2 Log Likehood menunjukan penurunan pada model awal (intercept only) jika dibandingkan dengan model final. Pada model awal nilai -2 Log Likehood sebesar 62,038 di mana memiliki nilai lebih besar dibandingkan pada nilai -2 Log Likehood model final, yaitu 16,799. Sedangkan hasil chi square sebesar 45,239 menunjukkan adanya penurunan dengan jumlah tersebut. Penurunan tersebut menunjukkan bahwa penambahan variabel independen pada model prediksi menjadikan model lebih baik dalam mengetahui pengaruh variabel independen, yaitu dualitas CEO-Chairman, jumlah komisaris, independensi komisaris, profitabilitas, leverage, likuiditas, harga saham, secure, jenis sukuk terhadap rating sukuk. Dengan hasil demikian maka bisa dikatakan bahwa model dalam penelitian ini sudah fit dengan data.

\section{Uji Goodness of Fit}

Uji goodness of fit test digunakan untuk menguji kelayakan model agar penjelasan pengaruh variabel dualitas CEO-Chairman, jumlah komisaris, independensi komisaris, profitabilitas, leverage, likuiditas, harga saham, secure, jenis sukuk terhadap rating sukuk layak dilakukan. Nilai uji goodness of fit test selanjutnya dibandingkan dengan nilai tabel chi square dengan kriteria pengambilan keputusan model yang dibuat cocok dengan data yang ada $\left(\mathrm{H}_{0}\right)$, dan model yang dibuat tidak cocok dengan data yang ada $\left(\mathrm{H}_{1}\right)$ di mana $\mathrm{H}_{0}$ ditolak jika $\mathrm{P}<0,05$, dan $\mathrm{H}_{1}$ diterima, sebaliknya $\mathrm{H}_{0}$ diterima jika $\mathrm{P}<0,05$ dan $\mathrm{H}_{1}$ ditolak.

Tabel 1.3. Goodness of Fit

\begin{tabular}{|c|r|r|r|}
\hline & Chi-Square & \multicolumn{1}{c|}{ df } & \multicolumn{1}{c|}{ Sig. } \\
\hline Pearson & 36,862 & 42 & 0,696 \\
\hline Deviance & 16,799 & 42 & 1,000 \\
\hline
\end{tabular}

Hasil output tabel 1.3. menunjukkan adanya nilai signifikansi sebesar 1,000 dengan nilai lebih dari 0,05. Artinya hasil uji hipotesisnya menunjukan $\mathrm{p}>0,05$ maka $\mathrm{H}_{0}$ diterima dan $\mathrm{H}_{1}$ ditolak. Model ini secara simultan memiliki kecocokan antara model yang dibuat dengan data yang ada.

\footnotetext{
${ }^{21}$ Ibid.
} 


\section{Uji Pseudo R-Square}

Pada uji Pseudo R-Square dimaksudkan untuk mengetahui tingkat ketepatan paling baik dalam menganalisis regresi di mana hal yang ditunjukkan oleh besarnya Pseudo R-Square. Pada regresi multinomial logistik nilai Pseudo $R$-Square terdapat tiga nilai, yaitu Cox and Snell, Negelkerke dan McFadden.

Tabel 1.4. Pseudo R-Square

\begin{tabular}{|l|l|}
\hline Cox and Snell &, 768 \\
Nagelkerke &, 888 \\
McFadden &, 729 \\
\hline
\end{tabular}

Tabel 1.4. di atas menunjukkan nilai Pseudo R-Square adalah sebesar 0,729 (nilai McFadden). Ini berarti variabel dependen dalam hal ini rating sukuk yang dapat dijelaskan oleh variabel independen, yaitu dualitas CEO-Chairman, jumlah komisaris, independensi komisaris, profitabilitas, leverage, likuiditas, harga saham, secure, jenis sukuk adalah sebesar $72,9 \%$, sisanya sebanyak $27,1 \%$ dijelaskan oleh variabel-variabel lain di luar model penelitian. Variabel-variabel di luar model penenlitian sebesar $27,1 \%$ ini dimungkinkan adalah variabel-variabel lain yang berpengaruh terhadap rating sukuk.

\section{Uji Likelihood Ratio Test}

Uji likelihood ratio test dilakukan untuk mengetahui kontribusi dari setiap variabel independen terhadap model. Selain itu juga digunakan untuk menguji signifikansi dari setiap variabel independen. Variabel yang menunjukkan kontrubusi pada model dan pengaruh signifikan dilihat pada model akhir -2 log-likelihood, jika signifikan $(\mathrm{p}<0.05)$ maka variabel independen memiliki kontribusi.

Tabel 1.5. Likelihood Ratio Test

\begin{tabular}{|l|r|r|r|r|}
\hline \multirow{2}{*}{ Effect } & \multicolumn{2}{|c|}{$\begin{array}{c}\text { Model Fitting } \\
\text { Criteria }\end{array}$} & \multicolumn{3}{|c|}{ Likelihood Ratio Tests } \\
\cline { 3 - 5 } & $\begin{array}{c}-2 \text { Log Likelihood of } \\
\text { Reduced Model }\end{array}$ & Chi-Square & df & \multicolumn{1}{|c|}{ Sig. } \\
\hline Intercept & 16,799 &, 000 & 0 &. \\
Jumlah Komisaris & 30,964 & 14,165 & 2 &, 001 \\
Independensi Komisaris & 23,499 & 6,700 & 2 &, 035 \\
\hline Profitabilitas & 26,471 & 9,672 & 2 &, 008 \\
Leverage & 23,064 & 6,265 & 2 &, 044 \\
Likuiditas & 33,208 & 16,409 & 2 &, 000 \\
\hline Harga Saham & 26,947 & 10,148 & 2 &, 006 \\
Dualitas CEO & 23,406 & 6,607 & 2 &, 037 \\
Secure & 25,626 & 8,827 & 2 &, 012 \\
Jenis Sukuk & 32,348 & 15,549 & 2 &, 000 \\
\hline
\end{tabular}

Hasil uji likelihood ratio test pada tabel 1.5. di atas menunjukkan bahwa variabel independen yang sesuai terhadap model yang dibuat adalah dualitas CEO-Chairman, jumlah 
komisaris, independensi komisaris, profitabilitas, leverage, likuiditas, harga saham, secure, jenis sukuk. Metode likelihood ratio test tidak hanya digunakan untuk menguji signifikansi keseluruhan model variabel, namun bisa juga menjadi uji keakuratan untuk mengetahui kontribusi tiap variabel independen terhadap variabel dependen. Dari hasil uji likelihood ratio test ini dapat digunakan untuk mengetahui pengaruh masing-masing variabel independen untuk menganalisis hasil uji hipotesisnya.

\section{Pengaruh Corporate Governence terhadap Rating Sukuk pada Perusahaan Korporasi di Indonesia}

Menurut Najmudin, corporate governance dalam Islam adalah sistem yang mengarahkan dan mengendalikan perusahaan untuk memenuhi tujuan perusahaan dengan melindungi kepentingan dan hak semua stakeholder dengan menggunakan konsep dasar pengambilan keputusan berdasarkan epistemologi sosial-ilmiah Islam yang didasarkan pada ketauhidan Allah. Salah satu prinsip corporate governance dalam Islam adalah șiddiq yang berarti kejujuran dalam apa yang disampaikan adalah keadaan yang sebenarnya. ${ }^{22}$

Hasil penelitian ini menunjukan bahwa variabel dualitas CEO-Chairman bernilai siginifikan 0,037 dengan chi square 6,607 lebih besar dari chi square tabel 5,9915, maka variabel dualitas CEO-Chairman dinilai berpengaruh positif terhadap rating sukuk. Berdasarkan teori agensi menurut Jensen, bahwa dualitas CEO-Chairman dapat melemahkan fokus tugas CEO. Namun, peran dari dualitas ini juga akan memperkuat fungsi CEO. Ketika CEO memiliki kekuatan dalam mengambil keputusan, maka akan memiliki lebih banyak keleluasaan untuk mempengaruhi keputusan yang akan diambil untuk kebaikan perusahaan itu sendiri. ${ }^{23}$

Variabel jumlah komisaris memiliki nilai siginifikan 0,001 dengan chi square 14,165 lebih besar dari chi square tabel 5,9915, maka variabel jumlah komisaris memiliki pengaruh terhadap rating sukuk. Di sini jumlah komisaris yang lebih besar dapat membantu mengawasi perusahaan dengan efektif untuk memenuhi tujuan perusahaan dan mempertahankan reputasi yang baik di pasar modal, seperti ketika jumlah anggota komisaris lebih besar dapat memberikan siklus yang berbeda dalam menjaga kewajiban tata kelola pengambilan keputusan untuk mendapatkan peringkat sukuk yang lebih baik.

Dan variabel independensi komisaris siginifikan 0,035 dengan chi square 6,700 lebih besar dari chi square tabel 5,9915, maka variabel independensi komisaris berpengaruh terhadap rating sukuk. Hal ini menjukan bahwa independensi komisaris diharapkan dapat mengontrol kebijakan-kebijakan yang diambil oleh dewan komisaris. Semakin banyak atau sedikitnya presentase dari indepensi komisaris akan mempengaruhi keputusan yang diambil dalam jumlah keseluruhan dewan komisaris, karena salah satu fungsi dari komisaris adalah sebagai pihak pengawas dalam perusahaan.

Hasil penelitian ini menunjukan bagaimana nilai kejujuran dalam Islam begitu penting sehingga kejujuran dalam pengawasan perusahaan menjadikan pengelolaan perusahaan bertumbuh lebih baik, selain itu akan menumbuhkan tingkat kepercayaan publik terhadap

\footnotetext{
22 Najmuddin, Manajemen Keuangan, 94.

${ }^{23}$ Michael C Jensen dan William H Meckling, "Theory of the Firm: Managerial Behavior, Agency Costs and Ownership Structure", Journal of Financial Economics, Volume 3, Nomor 4 (1976), 308.
} 
perusahaan semakin baik sehingga mempercayakan investasinya pada perusahaan tersebut. Secara empiris, penelitian ini didukung oleh penelitian Elhaj dengan menggunakan variabel corporate governance terhadap rating sukuk yang menyatakan bahwa peringkat sukuk berhubungan terhadap variabel pada corporate governence dengan proksi dualitas kepemimpinan CEO-Chairman, jumlah komisaris dan independensi komisaris. ${ }^{24}$

\section{Pengaruh Rasio Keuangan terhadap Rating Sukuk pada Perusahaan Korporasi di Indonesia}

Dalam penelitian ini menghasilkan variabel profitabilitas bernilai siginifikan 0,008 dengan chi square 9,672 lebih besar dari chi square tabel 5,9915, maka variabel profitabilitas dinilai berpengaruh terhadap rating sukuk. Pengaruh profitabilitas ini menunjukan tinggi rendahnya nilai dari profitabilitas perusahaan berakibat pada peringkat sukuk yang diperoleh karena ketika nilai profitabilitas tinggi menginterpretasikan baiknya pengelolaan perusahaan dalam mengelola serta memperoleh keuntungan, sehingga tingkat kesehatan dari perusahaan termasuk kesanggupan membayar sukuk pada pemegang sukuk semakin rendah resiko gagal bayarnya. Menurut Henny, ketika tingkat nilai profitabilitas dari perusahaan semakin tinggi menunjukan rendahnya risiko ketidakmampuan dalam membayar, selain itu jika risiko ketidakmampuan bayar perusahaan semakin rendah, maka rating dari obligasi akan semakin tinggi. ${ }^{25}$ Hal ini didukung oleh penelitian Elhaj yang menyatakan bahwa profitabilitas berpengaruh terhadap rating sukuk, ${ }^{26}$ begitu juga pada penelitian Pramesti ${ }^{27}$ dan Suprayogi ${ }^{28}$ bahwa profitabilitas mempengaruhi pemeringkatan sukuk.

Variabel leverage memiliki nilai siginifikan 0,044 dengan chi square 6,265 lebih besar dari chi square tabel 5,9915, maka variabel leverage memiliki pengaruh terhadap rating sukuk. Rasio leverage sendiri adalah indikator yang menunjukkan proporsi penggunaan utang dalam membiayai modal atau investasi yang dimiliki. Hal ini menginterpretsikan apabila nilai leverage semakin tinggi, maka modal yang dibiayai oleh utang semakin tinggi. Kondisi ini bisa mempengaruhi rating sukuk karena apabila beban dari perusahaan tersebut tinggi, maka dikhawatirkan risiko tidak mampunya perusahaan dalam membayar sukuk semakin tinggi. Hal ini sesuai penelitian sebelumnya yang menyatakan rating obligasi secara signifikan dipengaruhi oleh variabel leverage yang diproksi dengan $\mathrm{DER}^{29}$ di mana ketika perusahaan memiliki jumlah utang yang lebih sedikit dari jumlah modalnya maka bisa diartikan perusahaan mampu melunasi utang dengan modal yang dimiliki. Perusahaan diperkenankan memiliki utang dengan ketentuan utang tersebut bisa dikelola secara bijak dan memberikan manfaat positif bagi kegiatan oprasional perusahaan sehingga perusahaan mampu membayar

\footnotetext{
${ }^{24}$ Mohamed Abulgasem Elhaj, dkk, "The Influence of Corporate Governance, Financial Ratios, and Sukuk Structure on Sukuk Rating", Procedia Economics and Finance, Volume 31, Nomor 1 (2015), 68.

${ }^{25}$ Henny, "Pengaruh Faktor Akuntansi Terhadap Prediksi Peringkat Obligasi”, Journal of Accounting, Volume 20, Nomor 1 (2016), 92.

${ }^{26}$ Mohamed Abulgasem Elhaj, dkk, "The Influence of Corporate Governance”, 69.

${ }^{27}$ Wahyu Pramesti, “Analisis Pemeringkatan Sukuk”, 95.

28 Noven Suprayogi dan Devi Arum Saputri, "Faktor-Faktor Keuangan yang Mempengaruhi Rating Sukuk dengan Menggunakan Model Regresi Multinominal Logistik", Jurnal Ekonomi Syariah: Teori dan Terapan, Volume 5, Nomor 6 (2018), 437.

${ }^{29}$ Ninik Amalia, "Pemeringkatan Obligasi PT. Pefindo Berdasarkan Informasi Keuangan", Accounting Analysis Journal, Volume 2, Nomor 2 (2013), 183.
} 
margin atau bagi hasil dan kewajibannya pada saat jatuh tempo. Perusahaan dengan kondisi yang demikian akan lebih diminati investor karena memiliki kategori layak investasi. Dalam penelitian ini, pengaruh variabel leverage terhadap rating sukuk memiliki hasil yang berbeda dengan hasil penelitian terdahulu, seperti dalam penelitian Kustyaningrum menyatakan bahwa tidak adanya pengaruh secara parsial variabel laverage terhadap rating obligasi, ${ }^{30}$ begitu juga dalam Raimuna yang menyatakan variabel Leverage tidak berpengaruh terhadap rating sukuk. $^{31}$

Variabel likuiditas siginifikan 0,000 dengan chi square 16,409 lebih besar dari chi square tabel 5,9915, maka variabel likuiditas berpengaruh terhadap rating sukuk. Rasio likuiditas digunakan sebagai tolak ukur kemampuan jangka pendek perusahaan dengan menghitung aset lancar perusahaan relatif terhadap utang lancarnya. ${ }^{32}$ Pada variabel likuiditas apabila nilai dari likuiditas semakin tinggi, maka bisa diartikan kondisi keuangan pada perusahaan tersebut stabil sehingga kemampuan perusahaan dalam memenuhi kewajiban jangka pendeknya semakin baik. Pada kondisi ini, tingkat likuiditas dari perusahaan mempengaruhi rating sukuknya karena ketika kemampuan perusahaan dalam memenuhi kewajiban jangka pendeknya baik, maka bisa diinterpretasikan kesanggupan perusahaan dalam membayar sukuk kepada pemegang sukuk juga semakin baik. Dari hasil penelitian ini didukung secara empirik pada penelitian Suprayogi yang menunjukan bahwa likuiditas berpengaruh positif terhadap rating sukuk, ${ }^{33}$ begitu juga dalam Kustiyaningrum yang menyatakan likuiditas memiliki pengaruh terhadap peringkat obligasi. ${ }^{34}$

\section{Pengaruh Nilai Pasar terhadap Rating Sukuk pada Perusahaan Korporasi di Indonesia}

Hasil penelitian ini menunjukan bahwa nilai pasar dengan menggunakan variabel harga saham bernilai siginifikan 0,006 dengan nilai chi square 10,148 lebih besar dari chi square tabel 5,9915, maka variabel harga saham dinilai berpengaruh terhadap rating sukuk. Harga saham bisa menjadi interpretasi dari informasi yang tersedia untuk umum termasuk variabel akuntansi. ${ }^{35}$ Sehingga perolehan informasi perusahaan terhadap investor dalam hal ini nilai pasar dengan proksi harga saham dapat mempengaruhi rating sukuk. Hasil ini didukung secara empirik dalam penelitian Arundina yang membandingkan analisis multinominal logistic dan neural network inferences pada determinan penentu rating sukuk di Malaysia menyatakan bahwa nilai pasar yang diproksi dengan harga saham berpengaruh positif terhadap rating sukuk pada dua dua model analisis yang dilakukan. ${ }^{36}$

\footnotetext{
${ }^{30}$ Dinik Kustiyaningrum, dkk, "Pengaruh Leverage, Likuiditas”, 29.

${ }^{31}$ R. Raimuna dan E. Mutia, "Faktor- Faktor yang Mempengaruhi Peringkat Sukuk yang Ditinjau dari Faktor Akuntansi dan Non Akuntansi", Jurnal Ilmiah Mahasiswa Ekonomi Akuntansi (JIMEKA), Volume 3, Nomor 3 (2018), 509.

32 Abdul Halim Mamduh dan M. Hanafi, Analisis Laporan Keuangan (Yogyakarta: UPP STIM YKPN, 2014), 163.

${ }^{33}$ Noven Suprayogi dan Devi Arum Saputri, "Faktor-Faktor Keuangan”, 439.

${ }^{34}$ Dinik Kustiyaningrum, dkk, "Pengaruh Leverage, Likuiditas", 31.

35 Sudheer Chava dan Robert Jarrow, "Bankruptcy Prediction with Industry Effects", Review of Finance, Volume 8, Nomor 4 (2004), 541.

${ }^{36}$ Tika Arundina, dkk, "The Predictive Accuracy of Sukuk Ratings: Multinominal Logistic and Neural Network Inferences”, Pacific Basin Finance Journal, Volume 34, Nomor 2 (2015), 279.
} 


\section{Pengaruh Secure terhadap Rating Sukuk pada Perusahaan Korporasi di Indonesia}

Pada hasil penelitian ini menunjukan bahwa variabel secure bernilai siginifikan 0,012 dengan nilai chi square 8,827 lebih besar dari chi square tabel 5,9915, maka variabel secure dinilai berpengaruh terhadap rating sukuk. Menurut Brister, ${ }^{37}$ investor atau penanam modal lebih tertarik pada obligasi yang memiliki jaminan daripada obligasi yang tidak memiliki jaminan. Tanpa jaminan, pemegang sukuk tidak akan diprioritaskan jika penerbit sukuk default atau bangkrut. Sebaliknya, sukuk yang dijamin oleh pihak ketiga dapat melindungi kepentingan pemegang dari risiko kebangkrutan. Dengan demikian, sukuk yang dijamin cenderung diperingkat lebih tinggi dari sukuk yang tidak dijamin. ${ }^{38}$ Dalam penelitian ini, variabel secure didukung secara empirik yang menyatakan peringkat dari sukuk dipengaruhi oleh ada atau tidaknya secure atau status jaminan dari sukuk. ${ }^{39}$

\section{Pengaruh Jenis Sukuk terhadap Rating Sukuk pada Perusahaan Korporasi di Indonesia}

Hasil penelitian ini menunjukan bahwa variabel jenis sukuk bernilai siginifikan 0,000 dengan nilai chi square 15,549 lebih besar dari chi square tabel 5,9915, maka variabel jenis sukuk dinilai berpengaruh terhadap rating sukuk. Dalam penelitian ini menggunakan dua struktur sukuk, yaitu mudärabah dan ijärah. Ini menunjukan bahwa pemilihan jenis sukuk yang diterbitkan oleh perusahaan dapat mempengaruhi ratingnya. Pengaruh variabel jenis sukuk terhadap rating sukuk didukung pada studi empirik oleh Amirah dan Noryati menunjukan peringkat dari sukuk dipengaruhi oleh jenis sukuk khususnya sukuk murabahah menjadi variabel yang paling signifikan. ${ }^{40}$ Begitu pula dalam Elhaj yang menyatakan bahwa rating sukuk memiliki hubungan positif pada jenis sukuk memiliki dengan studi pada 25 perusahaan penerbit sukuk di Malaysia pada tahun 2008-2012. ${ }^{41}$ Begitu juga pada penelitian Arundina yang membandingkan analisis multinominal logistic dan neural network inferences pada determinan penentu rating yang menyatakan jenis sukuk berpengaruh pada rating sukuk. $^{42}$

\section{Kesimpulan}

Dari hasil pembahasan di atas, ada beberapa kesimpulan yang bisa diambil. Pertama, bahwa variabel dualitas CEO-Chairman dinilai berpengaruh terhadap rating sukuk yang berarti peran dualitas CEO-Chairman memiliki kekuatan dan keleluasaan dalam mengambil keputusan pengelolaan perusahaan sehingga bisa berpengaruh terhadap rating sukuk. Variabel jumlah komisaris memiliki pengaruh terhadap rating sukuk di mana jumlah komisaris yang lebih besar dapat membantu peengawasan pada perusahaan secara efektif untuk memenuhi tujuan perusahaan. Variabel independensi komisaris berpengaruh terhadap rating sukuk, maka semakin banyak atau sedikit persentase komisaris independen dapat mempengaruhi keputusan dewan komisaris sehingga berpengaruh terhadap rating sukuk. Kedua, variabel profitabilitas

\footnotetext{
${ }^{37}$ Bill M. Brister, dkk, “The Regulation Effect”, 518.

${ }^{38}$ Elvin Donaldson, Business Organization and Procedure (McGraw Hill: t.p., 1938), 173.

39 Nur Amirah Borhan dan Noryati Ahmad, "Identifying the Determinants of Malaysian Corporate Sukuk Rating", International Journal of Islamic and Middle Eastern Finance and Management, Volume 11, Nomor 3 (2018), 438.

${ }^{40}$ Ibid.

${ }^{41}$ Mohamed Abulgasem Elhaj, dkk, "The Influence of Corporate Governance", 71.

${ }^{42}$ Tika Arundina, dkk, "The Predictive Accuracy", 280.
} 
dinilai berpengaruh terhadap rating sukuk. Semakin tinggi tingkat profitabilitas perusahaan, maka diharapkan semakin tinggi kemampuan perusahaan dalam membayar sukuk saat jatuh tempo. Variabel leverage memiliki pengaruh terhadap rating sukuk. Semakin tinggi nilai leverage perusahaan, maka dapat diinterpretasikan semakin tinggi resiko pada perusahaan sehingga dikhawatirkan perusahaan tidak mampu membayar sukuk. Variabel likuiditas berpengaruh terhadap rating sukuk. Ketika nilai rasio likuiditas tinggi menunjukan kemampuan membayar hutang jangka pendek yang baik sehingga diharapkan perusahaan mampu membayar sukuk saat jatuh tempo.

Ketiga, bahwa nilai pasar dengan menggunakan variabel harga saham dinilai berpengaruh terhadap rating sukuk di mana harga saham sebagai interpretasi dari informasi akuntansi karena terbentuk dari perdagangan sekunder, perolehan informasi investor dapat mempengaruhi rating sukuk. Keempat, bahwa variabel secure dinilai berpengaruh terhadap rating sukuk. Ketika sukuk memiliki jaminan, maka dapat melindungi investor dari resiko ketidakmampuan perusahaan memenuhi pembayaran sukuk. Kelima, variabel jenis sukuk dinilai berpengaruh terhadap rating sukuk sehingga pemilihan jenis sukuk bisa mempengaruhi rating sukuk. Dalam hal ini, faktor jenis sukuk menjadi pembeda dari obligasi karena pemilihan akad dalam penerbitan sukuk akan mempengaruhi tingkat return dan resiko yang berbeda.

\section{Daftar Rujukan}

Ghozali, Imam dan Anis Chariri. Teori Akuntansi. Semarang: Badan Penerbit UNDIP, 2007.

Spence, Michael. "The Quarterly Journal of Economics", Job Market Signaling, Volume 87, Nomor 3 (1973).

Kustiyaningrum, Dinik, dkk. "Pengaruh Leverage, Likuiditas, Profitabilitas, dan Umur Obligasi Terhadap Peringkat Obligasi (Studi Pada Perusahaan Terbuka yang Terdaftar di Bursa Efek Indonesia)", Assets: Jurnal Akuntansi dan Pendidikan, Volume 5, Nomor 1 (2017).

Pramesti, Wahyu. "Analisis Pemeringkatan Sukuk: Perspektif Keuangan”, BISNIS: Jurnal Bisnis dan Manajemen Islam, Volume 5, Nomor 1 (2018).

Sugiyono. Metode Penelitian Kuantitatif Kualitatif dan R\&D. Bandung: Alfabeta, 2012.

Ghozali, Imam. Aplikasi Analisis Multivariate dengan Program IBM SPSS 21. Semarang: Badan Penerbit Universitas Diponegoro, 2013.

Huda, Nurul dan Edwin Mustafa Nasution. Investasi Pada Pasar Modal Syariah. Jakarta: Kencana, 2007.

al-Zuhaily, Wahbah. al-Fiqh al-Islam wa Adillatuhu (Fiqh Muamalah Perbankan Syariah), Tim Counterpart Bank Muamalat Indonesia. Jakarta: Bank Muamalat Indonesia, 1999.

Syafei, Rahmat. Fiqh Muamalah. Bandung: Pustaka Setia, 2000.

Brister, Bill M. dkk. "The Regulation Effect of Credit Ratings on Bond Interest Yield: The Case of Junk Bonds", Journal of Business Finance \& Accounting, Volume 21, Nomor 4 (1994).

Trisilo, Rudi Bambang. "Penerapan Akad Pada Obligasi Syariah dan Sukuk Negara (Surat Berharga Syariah Negara/SBSN)", Economic: Journal of Economic and Islamic Law, Volume 4, Nomor 1 (2014). 
Najmuddin. Manajemen Keuangan dan Aktualisasi Syar'iyyah Modern. Yogyakarta: Andi, 2011.

Bhatti, Ishaq dan Maria Bhatti. "Development in Legal Issues of Corporate Governance in Islamic Finance", Journal of Economic and Administrative Sciences, Volume 25, Nomor 1 (2009).

Sutojo, Siswanto dan E. John Aldridge. Good Corporate Governance: Tata Kelola Perusahaan yang Sehat. Jakarta: PT. Damar Mulia Pustaka, 2005.

Daniri, Mas Achmad. Konsep dan Penerapan Good Corporate Governance dalam Konteks Indonesia. Jakarta: Ray Indonesia, 2006.

Jensen, Michael C. dan William H. Meckling. "Theory of the Firm: Managerial Behavior, Agency Costs and Ownership Structure", Journal of Financial Economics, Volume 3, Nomor 4 (1976).

Elhaj, Mohamed Abulgasem, dkk. "The Influence of Corporate Governance, Financial Ratios, and Sukuk Structure on Sukuk Rating", Procedia Economics and Finance, Volume 31, Nomor 1 (2015).

Henny. "Pengaruh Faktor Akuntansi Terhadap Prediksi Peringkat Obligasi", Journal of Accounting, Volume 20, Nomor 1 (2016).

Suprayogi, Noven dan Devi Arum Saputri. "Faktor-Faktor Keuangan yang Mempengaruhi Rating Sukuk dengan Menggunakan Model Regresi Multinominal Logistik", Jurnal Ekonomi Syariah: Teori dan Terapan, Volume 5, Nomor 6 (2018).

Amalia, Ninik. "Pemeringkatan Obligasi PT. Pefindo Berdasarkan Informasi Keuangan", Accounting Analysis Journal, Volume 2, Nomor 2 (2013).

Raimuna, R. dan E. Mutia. "Faktor- Faktor yang Mempengaruhi Peringkat Sukuk yang Ditinjau dari Faktor Akuntansi dan Non Akuntansi", Jurnal Ilmiah Mahasiswa Ekonomi Akuntansi (JIMEKA), Volume 3, Nomor 3 (2018).

Mamduh, Abdul Halim dan M. Hanafi. Analisis Laporan Keuangan. Yogyakarta: UPP STIM YKPN, 2014.

Chava, Sudheer dan Robert Jarrow. "Bankruptcy Prediction with Industry Effects", Review of Finance, Volume 8, Nomor 4 (2004).

Arundina, Tika, dkk. "The Predictive Accuracy of Sukuk Ratings: Multinominal Logistic and Neural Network Inferences", Pacific Basin Finance Journal, Volume 34, Nomor 2 (2015).

Donaldson, Elvin. Business Organization and Procedure. McGraw Hill: t.p., 1938.

Borhan, Nur Amirah dan Noryati Ahmad. "Identifying the Determinants of Malaysian Corporate Sukuk Rating", International Journal of Islamic and Middle Eastern Finance and Management, Volume 11, Nomor 3 (2018). 